\title{
Road traffic accidents involving elderly people: an integrative review
}

Betise Mery Alencar Sousa Macau Furtado' (ID Ana Carolina Bezerra de Lima² ${ }^{\mathbb{D}}$ Ranna Carinny Gonçalves Ferreira ${ }^{3}$ (D)

\section{Abstract}

Objective: To identify the epidemiological and socio-demographic profile of elderly victims of traffic accidents reported in articles published in scientific literature from 2013 to 2018. Method: The Literatura Latino Americana em Ciências da Saúde (Latin American Literature in Health Sciences), Base de Dados de Enfermagem (Database in Nursing), Scientific Electronic Library Online, and Medical Literature Analysis and Retrieval System Online databases were used, with the guiding question being: What is the scientific production on traffic accidents involving elderly people? A total of 355 articles were found. After the application of the selection criteria, 16 were evaluated, and nine remained for final analysis. Results: The age range was 60 to 69 years and the majority of the sample were men, who were married and had low schooling. Being run over was the most frequent accident. The width of the traffic lanes and the time of the accident influenced the frequency and risk of accidents and the severity of the injuries. Conclusion: Younger elderly persons were the most affected, and being run over was the most frequent type of accident.

\footnotetext{
Universidade de Pernambuco (UPE), Faculdade de Enfermagem Nossa senhora das Graças (FENSG). Faculdade de Odontologia (FOP), Mestrado de Perícias Forenses. Recife, Pernambuco, Brasil.

2 Universidade de Pernambuco (UPE), Residência de enfermagem em Unidade de tratamento intensiva (UTI), Hospital da Restauração. Recife, Pernambuco, Brasil.

3 Universidade de Pernambuco (UPE), Faculdade de Enfermagem (FENSG). Recife, Pernambuco, Brasil.

Correspondence

Betise Mery Alencar Sousa Macau Furtado

Keywords: Accidents Traffic. Health of the Elderly. Wounds and Injuries. Health of the Elderly. Elderly Population. 


\section{INTRODUCTION}

Traffic accidents are one of the main causes of death in the young and adult population. This cause is also significant among the elderly, especially with the increasing size of the older population ${ }^{1-4}$.

A study on external causes carried out by the SEADE Foundation in the state of São Paulo, Brazil, found that car accidents and falls are among the main causes of death among the elderly. When the other causes of death among this population are compared, external causes have a lower impact, but are greater within the group itself ${ }^{5}$.

Although external causes affect the younger population more frequently, the risks of dying from accidents or violence increase dramatically among those over 60 . This is caused both by the condition of exposure to risk due to locomotion and other tasks that are part of activities of daily living, as well as by the inherent difficulties of age.

Among the accidents that can affect the elderly population are Road Traffic Accidents (RTA). The number of existing vehicles is a preponderant factor for the occurrence of these accidents, involving both automobiles and motorcycles, as they cause complications in the traffic in general, and increase the risks of this type of accident ${ }^{5,6}$. With the changing age of the population ${ }^{4,6}$, RTA suffered by the elderly have become a major public health problem, and one with an increasing trend ${ }^{7}$.

People in the 60 years or older age group have a higher mortality from external causes in Brazil, as well as hospitalizations from these causes within the Unified Health System (or SUS), with rates of 109 and 650 per 100,000 inhabitants, respectively, in 2008. Between 2008 and 2010, there were 413,139 hospitalizations for external causes among the elderly in the SUS, costing approximately $\mathrm{R} \$ 570$ million. These hospitalizations were mainly due to falls $(62.4 \%)$, traffic accidents $(8.1 \%)$ and unclassified external causes $(7 \%)^{8}$.

Between 2000 and 2010, the mortality rate from RTA increased from 18 to 22.5 deaths per 100,000 inhabitants in Brazil. Such accidents were also the second most frequent cause of hospitalizations in the SUS between 2002 and 2011, resulting in costs estimated at $\mathrm{R} \$ 50$ billion $^{9-11}$.

Although older people are living longer and more healthily, they face new challenges, among which are traumas resulting from RTA, which significantly affect this group ${ }^{10}$.

It was therefore felt that there was a need to better understand how RTA affect this population through the identification of published works on the subject in scientific literature, and from this knowledge provide a foundation to contribute to the preparation of preventive public policies to benefit this age group.

Therefore, the present study aimed to identify the epidemiological and sociodemographic profile of elderly victims of RTA through articles published in scientific literature from 2013 to 2018.

\section{METHOD}

An integrative review of literature was carried out, which consists of the creation of an evidencebased scientific framework. This form of knowledge production requires a methodological rigor and is effective for the analysis and critique of literature, constituting one of the main research modalities in the context of health ${ }^{12}$.

As a research strategy, the electronic databases Medical Literature Analysis and Retrieval System Online (PubMed), Latin American \& Caribbean Health Sciences Literature (LILACS), the Scientific Electronic Library Online (SciELO) virtual library and the ScienceDirect platform were used.

The inclusion criteria were: (a) articles indexed by descriptors registered in the Medical Subject Headings (MeSH) database: "Traffic Accidents", "Elderly", "Old Age", "Old Adults" and in the Health Sciences Descriptors (DeCS): "Traffic Accidents" and "Elderly"; (b) articles published from 2013 to 2018 involving people over 60 years of age and (c) articles that answered the research question. The exclusion criterion was published literature other 
than primary articles, excluding, in this manner, case studies, monographs, master's dissertations, doctoral theses, chapters of books and systematic reviews.

The survey was conducted between February and April 2018, with data collection performed at two different moments. The first was the selection of articles for a complete reading, the description of which is detailed in figure 1. Initially, 936 articles were established from the chosen descriptors. A total of
848 were discarded as they did not meet the inclusion criteria $(\mathrm{n}=840)$ or were duplicates $(\mathrm{n}=8)$, leaving 90 articles potentially eligible for the study.

From a careful reading of the titles and abstracts, 65 articles were excluded because they were outside the defined age group $(n=49)$ or did not relate to the studied subject $(\mathrm{n}=16)$ and, thus, 25 articles were chosen as they responded closely to the guiding research question proposed.

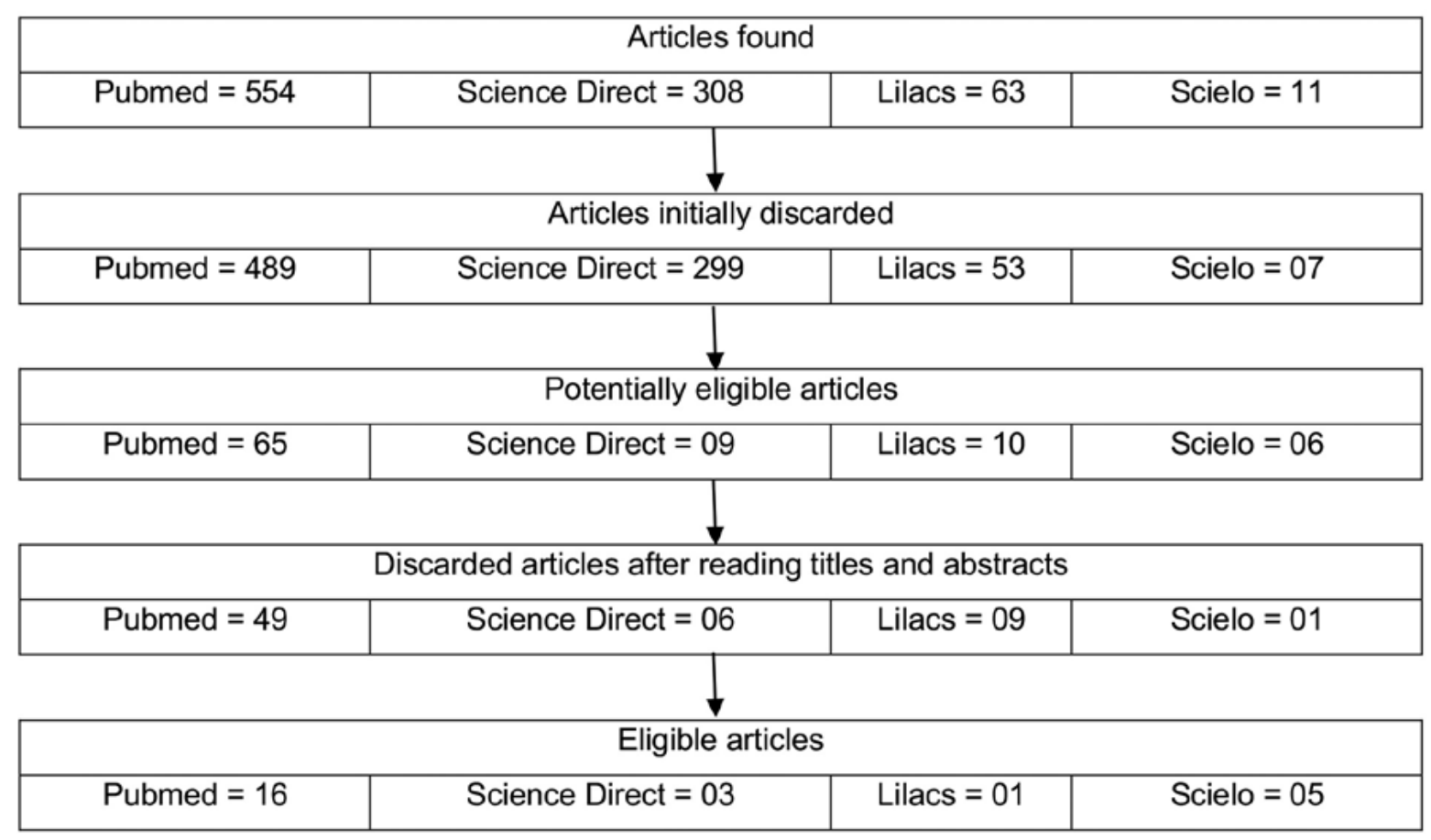

Figure 1. Selection process of articles included in the present review. Recife, Pernambuco, Brazil, 2018.

For the second part of the data collection, an instrument was created by the research team that contained the following items: article title, year of publication, country of affiliation of the main author, type of study and main results. Data analysis was performed in a descriptive manner, based on the Thematic-Categorical Content Analysis ${ }^{13}$. This process was divided into three stages, namely: preanalysis, exploration of material or coding and treatment of results - inference and interpretation.

\section{RESULTS}

Chart 1 lists the studies included in the review. 
Chart 1. Studies included in review, Recife, Pernambuco, 2018.

\begin{tabular}{|c|c|c|c|c|c|}
\hline Database & Títle of article & Author & $\begin{array}{l}\text { Year of } \\
\text { publication }\end{array}$ & $\begin{array}{l}\text { Country of } \\
\text { origin }\end{array}$ & Main results \\
\hline PubMed & $\begin{array}{l}\text { Associations of } \\
\text { Near-Miss Traffic } \\
\text { Incidents with } \\
\text { Attention and } \\
\text { Executive Function } \\
\text { among Older } \\
\text { Japanese Drivers }\end{array}$ & $\begin{array}{l}\text { Makizako H, } \\
\text { Shimada H, } \\
\text { Hotta R, Doi T, } \\
\text { Tsutsumimoto } \\
\text { K, Nakakubo S, } \\
\text { et al. }{ }^{14}\end{array}$ & 2018 & Japan & $\begin{array}{l}\text { Visual and auditory acuity } \\
\text { deficits increased the risk of } \\
\text { collisions of vehicles between } \\
\text { elderly drivers. Attention may } \\
\text { be one of the measurable and } \\
\text { modifiable contributors related } \\
\text { to car accidents in the general } \\
\text { population of older drivers. }\end{array}$ \\
\hline PubMed & $\begin{array}{l}\text { What are the } \\
\text { differences in injury } \\
\text { patterns of young } \\
\text { and elderly traffic } \\
\text { accident fatalities } \\
\text { considering death on } \\
\text { scene and death } \\
\text { in hospital? }\end{array}$ & $\begin{array}{l}\text { Heinrich D, } \\
\text { Holzmann } \\
\text { C, Wagner A, } \\
\text { Fischer A, Pfeifer } \\
\text { H, Graw M, et } \\
\text { al. }\end{array}$ & 2017 & Germany & $\begin{array}{l}\text { The majority of pedestrian } \\
\text { deaths were caused by } \\
\text { polytrauma. Most deaths at } \\
\text { the scene of the crash were } \\
\text { due to thoracic and pelvic } \\
\text { injuries, while in hospital the } \\
\text { most prevalent were abdominal } \\
\text { injuries. }\end{array}$ \\
\hline PubMed & $\begin{array}{l}\text { Age-related } \\
\text { differences in fatal } \\
\text { intersection crashes } \\
\text { in the United States }\end{array}$ & $\begin{array}{l}\text { Lombardi DA, } \\
\text { Horrey WJ, } \\
\text { Courtney TK. }{ }^{16}\end{array}$ & 2017 & USA & $\begin{array}{l}\text { Accidents involving the elderly } \\
\text { mostly occurred during the day, } \\
\text { from Tuesday to Friday, with } \\
\text { a lower collision speed than in } \\
\text { accidents involving younger } \\
\text { people. Older drivers were } \\
\text { more likely to make mistakes } \\
\text { regarding the culpability of the } \\
\text { accident. }\end{array}$ \\
\hline PubMed & $\begin{array}{l}\text { Features of fatal } \\
\text { injuries in older } \\
\text { cyclists in vehicle- } \\
\text { bicycle accidents in } \\
\text { Japan }\end{array}$ & $\begin{array}{l}\text { Matsui Y, Oikawa } \\
\text { S, Hitosugi M. }{ }^{17}\end{array}$ & 2017 & Japan & $\begin{array}{l}\text { Head injuries were the most } \\
\text { common causes of cyclist } \\
\text { fatalities after collision with a } \\
\text { vehicle among those aged over } \\
75 \text { years, with severe injuries } \\
\text { even at low speeds. }\end{array}$ \\
\hline ScienceDirect & $\begin{array}{l}\text { Predictors of older } \\
\text { drivers' involvement } \\
\text { in rapid deceleration } \\
\text { events }\end{array}$ & $\begin{array}{l}\text { Chevalier A, } \\
\text { Coxon K, } \\
\text { Chevalier AJ, } \\
\text { Clarke E, Rogers } \\
\text { K, Brown J, et } \\
\text { al. }^{18}\end{array}$ & 2017 & Australia & $\begin{array}{l}64 \% \text { of participants were } \\
\text { involved in at least one rapid } \\
\text { deceleration event over one } \\
\text { year, with most of those } \\
\text { involved being older drivers } \\
\text { with declining sensitivity and } \\
\text { reduced confidence. }\end{array}$ \\
\hline PubMed & $\begin{array}{l}\text { Elderly road } \\
\text { collision injury } \\
\text { outcomes associated } \\
\text { with seat positions } \\
\text { and seatbelt use in a } \\
\text { rapidly aging society } \\
\text { - A case study in } \\
\text { South Korea }\end{array}$ & Noh Y, Yoon Y. ${ }^{19}$ & 2017 & $\begin{array}{l}\text { South } \\
\text { Korea }\end{array}$ & $\begin{array}{l}\text { When younger ( } 65-74 \text { years) and } \\
\text { older ( } 75 \text { years or more) elderly } \\
\text { persons were compared, it was } \\
\text { observed that older individuals } \\
\text { were more likely to suffer } \\
\text { serious injury. Severe injuries } \\
\text { due to the absence of seat belts } \\
\text { were also more frequent in the } \\
\text { elderly. The proper application } \\
\text { of the use of safety restrictions } \\
\text { plays an important role in } \\
\text { reducing injuries among the } \\
\text { elderly in these accidents. }\end{array}$ \\
\hline
\end{tabular}




\begin{tabular}{|c|c|c|c|c|c|}
\hline Database & Títle of article & Author & $\begin{array}{l}\text { Year of } \\
\text { publication }\end{array}$ & $\begin{array}{l}\text { Country of } \\
\text { origin }\end{array}$ & Main results \\
\hline LILACS & $\begin{array}{l}\text { Trends in mortality } \\
\text { from road traffic } \\
\text { accidents in the } \\
\text { elderly in Brazil }\end{array}$ & $\begin{array}{l}\text { Scolari GAS, } \\
\text { Derhun FM, } \\
\text { Rossoni DF, } \\
\text { MathiasTAF, } \\
\text { Fernando CAM, } \\
\text { Carreira L. }^{20}\end{array}$ & 2017 & Brazil & $\begin{array}{l}27 \% \text { of registered causes } \\
\text { of death were due to road } \\
\text { traffic accidents. There were } \\
\text { greater growing trends in: the } \\
\text { northeast region, accidents } \\
\text { involving elderly pedestrians, } \\
\text { cyclists, motorcyclists and } \\
\text { occupants of automobiles. The } \\
\text { elderly are more susceptible to } \\
\text { being knocked down. }\end{array}$ \\
\hline SciELO & $\begin{array}{l}\text { Trauma from traffic } \\
\text { accidents among the } \\
\text { elderly: risk factors } \\
\text { and consequences }\end{array}$ & $\begin{array}{l}\text { Santos AMR, } \\
\text { Rodrigues RAP, } \\
\text { Diniz MA. }{ }^{21}\end{array}$ & 2017 & Brazil & $\begin{array}{l}\text { The elderly were between } \\
60 \text { and } 79 \text { years of age, male, } \\
\text { married, with elementary school } \\
\text { education, pedestrians, followed } \\
\text { by motorcyclists, and not drunk. }\end{array}$ \\
\hline ScienceDirect & $\begin{array}{l}\text { Pedestrian injury risk } \\
\text { and the effect of age }\end{array}$ & $\begin{array}{l}\text { Niebuhr T, Junge } \\
\text { M, Rosén E. }{ }^{22}\end{array}$ & 2016 & Germany & $\begin{array}{l}\text { Age and physical conditions } \\
\text { are the main risk factors for } \\
\text { traffic injuries, and age groups } \\
\text { from the youngest and oldest } \\
\text { extremities present a higher } \\
\text { risk of fatalities. The risk for } \\
\text { the elderly is double that of } \\
\text { adults, with more serious } \\
\text { consequences for elderly } \\
\text { persons over } 65 \text { years. }\end{array}$ \\
\hline PubMed & $\begin{array}{l}\text { The characterization } \\
\text { of drug and alcohol } \\
\text { use among senior } \\
\text { drivers fatally } \\
\text { injured in U.S. motor } \\
\text { vehicle collisions, } \\
20082012\end{array}$ & $\begin{array}{l}\text { Rudisill TM, } \\
\text { Zhu M, Abate } \\
\text { M, Davidov D, } \\
\text { Delagarza V, } \\
\text { Long DL, et al. }^{23}\end{array}$ & 2016 & USA & $\begin{array}{l}20 \% \text { of the tested drivers were } \\
\text { considered drug-positive. } \\
\text { The highest prevalence was } \\
\text { in the elderly of } 65-69 \text { years. } \\
\text { The most commonly reported } \\
\text { drugs were antidepressants } \\
\text { and narcotics, as well as } \\
\text { benzodiazepines. Those who } \\
\text { tested positive for drugs were } \\
43 \% \text { more likely to not be } \\
\text { wearing a seat belt at the time } \\
\text { of the collision. }\end{array}$ \\
\hline PubMed & $\begin{array}{l}\text { Age-Related } \\
\text { Differences in } \\
\text { Vehicle Control } \\
\text { and Eye Movement } \\
\text { Patterns at } \\
\text { Intersections: Older } \\
\text { and Middle-Aged } \\
\text { Drivers }\end{array}$ & $\begin{array}{l}\text { Yamani Y,Horrey } \\
\text { WJ, Liang Y, } \\
\text { Fisher DL. }^{24}\end{array}$ & 2016 & USA & $\begin{array}{l}\text { Older drivers had difficulty } \\
\text { performing simultaneous tasks. } \\
\text { Older drivers (over } 70 \text { years) } \\
\text { have a high risk of a fatal vehicle } \\
\text { accidents at intersections, as } \\
\text { elderly drivers generally do not } \\
\text { look twice for potential hazards } \\
\text { at intersections. }\end{array}$ \\
\hline Scielo & $\begin{array}{l}\text { Trauma among the } \\
\text { elderly: access to } \\
\text { the health system } \\
\text { through mobile pre- } \\
\text { hospital treatment. }\end{array}$ & $\begin{array}{l}\text { Silva HC, Pessoa } \\
\text { RL, Menezes } \\
\text { RMP. }^{25}\end{array}$ & 2016 & Brazil & $\begin{array}{l}\text { Among the victims of trauma, } \\
\text { women were most prevalent, } \\
\text { and were victims of falls, } \\
\text { with pre-hospital treatment } \\
\text { (basic life support), who were } \\
\text { then transported to a tertiary } \\
\text { referral unit. }\end{array}$ \\
\hline
\end{tabular}




\begin{tabular}{|c|c|c|c|c|c|}
\hline Database & Títle of article & Author & $\begin{array}{l}\text { Year of } \\
\text { publication }\end{array}$ & $\begin{array}{l}\text { Country of } \\
\text { origin }\end{array}$ & Main results \\
\hline Scielo & $\begin{array}{l}\text { Instruction program } \\
\text { with emphasis on } \\
\text { self-care practices } \\
\text { for elderly motorists }\end{array}$ & $\begin{array}{l}\text { Almeida MHM, } \\
\text { Caromano FA, } \\
\text { Ribeiro SS, } \\
\text { Batista MPP. }^{26}\end{array}$ & 2016 & Brazil & $\begin{array}{l}54 \% \text { of respondents reported } \\
\text { difficulty driving, } 42.9 \% \\
\text { reported emotional difficulties, } \\
\text { and another } 42.9 \% \text { said they } \\
\text { had physical, sensory and/or } \\
\text { cognitive difficulties. There } \\
\text { was also a deficit related to } \\
\text { education, as well as inspection } \\
\text { and punishment of traffic } \\
\text { violations. }\end{array}$ \\
\hline PubMed & $\begin{array}{l}\text { Impact of road } \\
\text { traffic accidents on } \\
\text { the elderly }\end{array}$ & $\begin{array}{l}\text { Etehad H, } \\
\text { Yousefzadeh- } \\
\text { ChabokSh, } \\
\text { Davoudi- } \\
\text { Kiakalaye A, } \\
\text { Dehnadi AM, } \\
\text { Hemati H, } \\
\text { Mohtasham- } \\
\text { Amiri Z. }\end{array}$ & 2015 & Iran & $\begin{array}{l}\text { The study divided the elderly } \\
\text { into }<75 \text { and }>75 \text { years of age } \\
\text { and, when comparing the two, } \\
\text { found that the majority of the } \\
\text { injured were male, married, } \\
\text { pedestrians, affected by TBI } \\
\text { and extremity fractures, while } \\
\text { the elderly persons }<75 \text { years } \\
\text { remained hospitalized for } \\
\text { longer, and mortality was higher } \\
\text { among the }>75 \text { years group }\end{array}$ \\
\hline PubMed & $\begin{array}{l}\text { Incidence and related } \\
\text { factors of traffic } \\
\text { accidents among the } \\
\text { older population in a } \\
\text { rapidly aging society }\end{array}$ & $\begin{array}{l}\text { Hong K, Lee } \\
\text { KM, Jang S. }\end{array}$ & 2015 & $\begin{array}{l}\text { South } \\
\text { Korea }\end{array}$ & $\begin{array}{l}\text { The incidence of traffic } \\
\text { accidents among elderly } \\
\text { Koreans was estimated at } \\
11.74 / 1,000 \text { inhabitants for men } \\
\text { and } 7.65 / 1,000 \text { inhabitants for } \\
\text { women. The most common } \\
\text { risk factors were: depressive } \\
\text { symptoms for both genders, } \\
\text { employability for males and } \\
\text { comorbidities such as arthritis } \\
\text { for females. }\end{array}$ \\
\hline SciELO & $\begin{array}{l}\text { Elderly persons } \\
\text { treated in urgent care } \\
\text { services in Brazil: } \\
\text { a study of falls and } \\
\text { accidents in traffic. }\end{array}$ & $\begin{array}{l}\text { Freitas MG, } \\
\text { Bonolo PF, } \\
\text { Moraes EN, } \\
\text { Machado CJ. }{ }^{29}\end{array}$ & 2015 & Brazil & $\begin{array}{l}\text { Main victims of falls: women } \\
\text { with low levels of schooling, } \\
\text { without a current job. Main } \\
\text { victims of traffic accidents: } \\
\text { younger men. Complications } \\
\text { were found at similar levels in } \\
\text { both sexes. }\end{array}$ \\
\hline PubMed & $\begin{array}{l}\text { The effects of age, } \\
\text { gender, and crash } \\
\text { types on drivers' } \\
\text { injury-related health } \\
\text { care costs }\end{array}$ & $\begin{array}{l}\text { Shen S, Neyens } \\
\text { DM. }^{30}\end{array}$ & 2015 & USA & $\begin{array}{l}\text { The estimate of average health } \\
\text { costs in in US dollars in } 2007 \\
\text { was } \$ 2310 \text { for men }>65 \text { years } \\
\text { and } \$ 2055 \text { for women }>65 \\
\text { years. In terms of age and } \\
\text { gender, drivers in older groups } \\
\text { have higher health care costs } \\
\text { than drivers in younger age } \\
\text { groups. The former have a } \\
\text { reduced capacity to recover } \\
\text { from lesions, leading to longer } \\
\text { hospitalization time }\end{array}$ \\
\hline
\end{tabular}




\begin{tabular}{|c|c|c|c|c|c|}
\hline Database & Títle of article & Author & $\begin{array}{l}\text { Year of } \\
\text { publication }\end{array}$ & $\begin{array}{l}\text { Country of } \\
\text { origin }\end{array}$ & Main results \\
\hline PubMed & $\begin{array}{l}\text { Street crossing } \\
\text { behavior in } \\
\text { younger and older } \\
\text { pedestrians: an eye- } \\
\text { and head-tracking } \\
\text { study }\end{array}$ & $\begin{array}{l}\text { Zito GA, Cazzoli } \\
\text { D, Scheffler L, } \\
\text { JägerM, Müri } \\
\text { RM, Mosimann } \\
\text { UP, et al. }\end{array}$ & 2015 & Switzerland & $\begin{array}{l}\text { Elderly persons performed } \\
\text { significantly worse on the } \\
\text { visual acuity test. Older } \\
\text { participants significantly } \\
\text { overestimated their walking } \\
\text { speed, but they needed more } \\
\text { time to complete the crossing. } \\
\text { Older pedestrians have more } \\
\text { difficulty analyzing the } \\
\text { movement of an approaching } \\
\text { car when it is still far away, } \\
\text { increasing risky decisions and } \\
\text { decreasing performance at the } \\
\text { intersection. }\end{array}$ \\
\hline ScienceDirect & $\begin{array}{l}\text { Crossing a two-way } \\
\text { street: comparison } \\
\text { of young and old } \\
\text { pedestrians }\end{array}$ & $\begin{array}{l}\text { Dommes A, } \\
\text { Cavallo V, } \\
\text { Dubuisson JB, } \\
\text { Tournier I, } \\
\text { Vienne F. }^{32}\end{array}$ & 2014 & USA & $\begin{array}{l}\text { Reduced functional skills } \\
\text { increase the risk of collision. } \\
\text { The elderly presented flaws } \\
\text { when required to increase } \\
\text { the speed and the length of } \\
\text { their steps in comparison } \\
\text { with younger people. The } \\
\text { elderly also had difficulty } \\
\text { processing information from } \\
\text { the visual scene, as well as not } \\
\text { looking directly at traffic, in } \\
\text { addition to making more risky } \\
\text { decisions compared to young } \\
\text { participants. }\end{array}$ \\
\hline PubMed & $\begin{array}{l}\text { Comorbidities and } \\
\text { Crash Involvement } \\
\text { among Younger and } \\
\text { Older Drivers }\end{array}$ & $\begin{array}{l}\text { Papa M, Boccardi } \\
\text { V, Prestano R, } \\
\text { Angellotti E, } \\
\text { Desiderio M, } \\
\text { Marano L, et al. }{ }^{33}\end{array}$ & 2014 & Italy & $\begin{array}{l}\text { The burden of comorbidity is } \\
\text { a self-limiting factor among } \\
\text { elderly drivers, since the } \\
\text { increase in comorbidities is } \\
\text { associated with a reduction in } \\
\text { involvement in collisions. Thus, } \\
\text { the burden of comorbidities is } \\
\text { a predictor of involvement in } \\
\text { traffic accidents, regardless of } \\
\text { gender. }\end{array}$ \\
\hline PubMed & $\begin{array}{l}\text { Association Between } \\
\text { Vision Impairment } \\
\text { and Driving } \\
\text { Exposure in Older } \\
\text { Adults Aged } 70 \\
\text { Years and Over: A } \\
\text { Population-Based } \\
\text { Examination }\end{array}$ & $\begin{array}{l}\text { Sandlin D, } \\
\text { McGwin Jr G, } \\
\text { Owsley C. }{ }^{34}\end{array}$ & 2014 & USA & $\begin{array}{l}\text { Reduced visual processing } \\
\text { speed was the strongest risk } \\
\text { factor for the involvement } \\
\text { of older drivers in vehicle } \\
\text { collisions. Self-regulation was } \\
\text { a highly adaptive strategy for } \\
\text { reducing exposure to this risk. }\end{array}$ \\
\hline
\end{tabular}




\begin{tabular}{|c|c|c|c|c|c|}
\hline Database & Títle of article & Author & $\begin{array}{l}\text { Year of } \\
\text { publication }\end{array}$ & $\begin{array}{l}\text { Country of } \\
\text { origin }\end{array}$ & Main results \\
\hline PubMed & $\begin{array}{l}\text { Mature Driver Laws } \\
\text { and State Predictors } \\
\text { of Motor Vehicle } \\
\text { Crash Fatality Rates } \\
\text { Among the Elderly: } \\
\text { A Cross-sectional } \\
\text { Ecological Study }\end{array}$ & $\begin{array}{l}\text { Bell TM, Qiao N, } \\
\text { Zarzaur BL. }\end{array}$ & 2014 & USA & $\begin{array}{l}\text { Overweight and a higher } \\
\text { percentage of elderly persons } \\
>65 \text { years with university } \\
\text { degrees were associated with an } \\
\text { increase in the rate of collisions } \\
\text { between vehicles. Greater } \\
\text { access to health services, such } \\
\text { as primary care, access to } \\
\text { medication and emergency } \\
\text { surgeries, were associated with } \\
\text { lower rates of fatality. }\end{array}$ \\
\hline PubMed & $\begin{array}{l}\text { Gender differences } \\
\text { among older drivers } \\
\text { in a comprehensive } \\
\text { driving evaluation }\end{array}$ & $\begin{array}{l}\text { Classen S, Wang } \\
\text { Y, Crizzle AM, } \\
\text { Winter SM, } \\
\text { Lanford DN. }{ }^{36}\end{array}$ & 2013 & USA & $\begin{array}{l}\text { Older female drivers presented } \\
\text { more self-reported avoidance } \\
\text { behaviors in relation to } \\
\text { interstate/highway driving, } \\
\text { driving in the rain, and driving } \\
\text { at night. Contrast analysis by } \\
\text { gender and age revealed that } \\
\text { more emphasis should be given } \\
\text { to the } 75 \text {-year-old male and } \\
\text { female group for failing the } \\
\text { road test. }\end{array}$ \\
\hline PubMed & $\begin{array}{l}\text { Effect of Driver's } \\
\text { Age and Side of } \\
\text { Impact on Crash } \\
\text { Severity along Urban } \\
\text { Freeways: A Mixed } \\
\text { Logit Approach }\end{array}$ & $\begin{array}{l}\text { Haleem K, Gan } \\
\text { A. }^{37}\end{array}$ & 2013 & USA & $\begin{array}{l}\text { Driver's age was an important } \\
\text { predictor, and impacts from } \\
\text { injuries, especially side impacts, } \\
\text { were greater among elderly } \\
\text { drivers. }\end{array}$ \\
\hline SciELO & $\begin{array}{l}\text { Comparative study } \\
\text { of trauma among } \\
\text { the elderly and } \\
\text { non-elderly in a } \\
\text { University Hospital } \\
\text { in Curitiba }\end{array}$ & $\begin{array}{l}\text { Broska Júnior } \\
\text { CA, Folchini AB, } \\
\text { Ruediger RR. }{ }^{38}\end{array}$ & 2013 & Brazil & $\begin{array}{l}\text { The majority of trauma care } \\
\text { in the elderly population was } \\
\text { for women. Traffic accidents } \\
\text { were the } 2 \text { nd most frequent } \\
\text { cause, with being knocked } \\
\text { down predominating, while the } \\
\text { elderly are most susceptible to } \\
\text { femoral fractures and TBI. }\end{array}$ \\
\hline
\end{tabular}

\section{DISCUSSION}

Globally, trauma cases are the fifth highest cause of mortality among the elderly, with cases of Road Traffic Accidents (RTA) contributing to this increase ${ }^{35}$. In Brazil, the RTA-related death rate among elderly individuals has been increasing since 1996, especially in the northeast region of the country ${ }^{20}$.

The demographic profile identified in several studies reveals that younger elderly persons, especially in the 60-69 age group, are the main victims of traffic accidents $^{16,21,27,29,38}$. However, health care costs are higher for the population of drivers aged over 65 years, as they are more likely to suffer more severe traumatic injuries and have a lower recovery capacity for these injuries than younger elderly persons, thus leading to longer hospitalization and higher costs ${ }^{18,19,30,37}$.

When the results were analyzed by gender, men were the most affected, which may be related to their greater movement around the urban perimeter of cities, due to their greater involvement in leisure activities and as participants in the labor market ${ }^{30,36}$. 
In addition, there is a greater proportion of RTA among married elderly persons, as well as those with lower schooling, as this is one of the determinants for a greater occurrence of traumatic lesions ${ }^{21,29}$.

Risk factors that increase the vulnerability of the elderly population to traffic accidents may be related to the aging process itself, the prevalence of comorbidities, alcohol use, polypharmacy, traffic dynamics and the structural difficulties of places the elderly attend ${ }^{21,22,27,37}$.

When comparing risk factors between genders, employability is found to be the greatest factor for males, with arthritis the most frequent comorbidity among females, and depressive symptoms evident factors for both genders ${ }^{28}$. Being overweight and elderly people over 65 with university degrees were other risk factors cited ${ }^{35}$.

Another important risk factor was the use of alcohol and other drugs. One study that characterized such use in elderly drivers involved in fatal automobile collisions in the USA found that among drivers considered drug-positive, there was a $43 \%$ greater tendency to be without a seat belt at the time of the collision. The most commonly reported drugs were antidepressants and narcotics, as well as benzodiazepines, many of which can alter driving ability if not prescribed and administered properly ${ }^{23}$.

Literature shows that elderly pedestrians are the most vulnerable to traffic accidents. This may be explained, in addition to the functional conditions of the elderly, by current traffic conditions and improper driving behaviors, such as carelessness on the part of car drivers and motorcycle riders, as well as situations where the elderly cross the road away from crossings or when the red light is showing for pedestrians ${ }^{15,21,38}$. Such situations potentiate trauma events in traffic and reaffirm their status as a public health problem ${ }^{25}$.

The predominance of being knocked down among traffic accidents involving the elderly is partly related to the difficulty these pedestrians have when crossing the road, as cognitive decline is accentuated by increases in age. A study also showed the unsafe behavior of elderly people when crossing two-way streets, where they have difficulties in increasing step speed and length in comparison with young people $^{32}$. A greater risk was also perceived among elderly drivers when decelerating vehicles due to reduced sensitivity and confidence ${ }^{18}$.

A study in Switzerland compared the behavior of young and old people at the intersection of a lane, and found that the latter looked more towards the ground than to both sides of the street before crossing than the former ${ }^{31}$. This was justified by the fact that the elderly do not generally take a second look for potential hazards at intersections ${ }^{24}$.

Regarding the day of the week, time of occurrence and speed of collision, when compared to traffic accidents involving younger people, accidents involving elderly people were more frequent during the day, from Tuesday to Friday, and involved a lower collision speed ${ }^{16}$.

The most commonly reported injury patterns were traumatic brain injuries (TBI), due to the impact of parts of the vehicle or throwing the victim onto the road, and limb fractures due to the reduction in the bone mineral content characteristic of aging ${ }^{22,27,38}$. In addition, it was also identified that in the elderly, most of the deaths at the scene of the accident were due to thoracic and pelvic injuries, while in hospitals the majority of deaths were due to abdominal injuries ${ }^{15}$. Although these lesions may be conveniently treated, some elderly cyclists died because rescue teams did not identify early retroperitoneal bleeding after pelvic fractures, which require the careful clinical evaluation by the team that provides first response care to the injured elderly person ${ }^{17}$.

In contrast, comorbidities help to reduce the risk of the elderly being victims of a RTA event, as they employ self-regulating behaviors. These behaviors are characterized by the self-reported decision to adopt protective strategies in traffic when perceiving their weakened physical condition, such as reducing their exposure to traffic, driving a vehicle at lower speeds and avoiding driving at night, which becomes preventive behavior ${ }^{14,20,33,34,36}$.

With regard to the impacts of traffic accidents on the elderly population, it is known that this type of event can negatively affect the functional capacity 
of such individuals, depending on the severity of the trauma. Immobilizations were the most frequent results, and the greater the intensity of the trauma, the more serious the consequences and the behavior adopted $^{26}$. It was evidenced that the elderly are more predisposed to suffering fractures or trauma to the cranial and vertebral column ${ }^{38}$.

One initiative worthy of note involved the development of a mentoring program for elderly drivers on driving difficulties associated with aging, encouraging self-care ${ }^{26}$. From this perspective, health services that care for the elderly, irrespective of the level of complexity, must be prepared to meet the specifics of trauma among this public, investing in professional training, infrastructure, health education, self-care practice and family participation ${ }^{24}$. These and other initiatives can serve as incentives to prevent the growth of the morbidity and mortality of elderly people due to traffic accidents and should be stimulated in the various contexts of care of this population.

The limitations of the present study concern the heterogeneity of the studies included in the review in terms of the discussion of the results, which may have hampered a more consistent analysis. The descriptors selected may not have found all the published studies. In addition, many of the articles surveyed are restricted access, which can be considered as a limiting factor. It is important that more studies are carried out in the area of gerontology and geriatrics involving traffic accidents.

\section{REFERENCES}

1. Instituto Brasileiro de Geografia e Estatística, Diretoria de Pesquisas, Coordenação de População e Indicadores Sociais. Síntese de Indicadores Sociais: uma análise das condições de vida da população brasileira [Internet]. Rio de Janeiro: IBGE; 2013 [acesso em 10 ago. 2018]. Disponível em: https://biblioteca.ibge.gov.br/ visualizacao/livros/liv98965.pdf

2. Simões CCS. Relações entre as alterações históricas na dinâmica demográfica brasileira e os impactos decorrentes do processo de envelhecimento da população [Internet]. Rio de Janeiro: IBGE; 2016 [acesso em 10 ago. 2018]. Disponível em: https:// biblioteca.ibge.gov.br/pt/biblioteca-catalogo?view= detalhes\&id $=298579$

\section{CONCLUSION}

According to this review, the profile of the elderly persons suffering traffic accidents was: elderly persons in the age group of 60 to 69 years, males, married, with low schooling and who worked. Pedestrians were the most vulnerable, with a predominance of being knocked down. The accidents occurred most often during the day, and cranio-encephalic trauma was the most frequent injury.

In view of the results, it can be inferred that there is a need to invest in the area of urgent and emergency care, in the planning of actions that contribute to the preparation of health teams for the integral care for the elderly, noting their particular characteristics, related to the frailty of age, such as the pathophysiological alterations that can compromise the quality of life of these individuals.

A fresh approach should be taken among professionals who work directly with traffic in cities with an elderly population, with the aim of training such individuals and raising their awareness about the treatment of the elderly, avoiding greater harm.

It is hoped that other researchers are encouraged to carry out further studies in the areas of geriatrics and gerontology involving Road Traffic Accidents (RTA) in order to create strategies where this population can have more freedom in their mobility without the risk of accidents, and with a better quality of life.

3. United Nations Population Fundation. 2011 Annual Report: Delivering results in a world of 7 billion [Internet]. New York: UNFPA; 2012 [acesso em 10 ago. 2018]. Disponível em: https://www.unfpa.org/ publications/unfpa-annual-report-2011

4. World Health Organization. Informe mundial sobre el envejecimiento y la salud [Internet]. Geneva: WHO; 2015 [acesso em 10 ago. 2018]. Disponível em: https://www.who. int/ageing/publications/world-report-2015/es/

5. Camargo ABM. Idosos e mortalidade: preocupante relação com as causas externas [Internet]. Prim Anál Seade [Internet] 2016 [acesso em 15 nov. 2018];35:4-20. Disponível em: http://www.seade.gov.br/wp-content/ uploads/2016/03/Primeira_Analise_35_fev16.pdf 
6. Veras RP. International experiences and trends in health care models for the elderly. Ciênc Saúde Colet [Internet]. 2012 [acesso em 15 jan. 2019];17(1):231-8. Disponível em: http://www. scielo.br/scielo.php?script=sci_arttext\&pid=S1413$81232012000100025 \& \operatorname{lng}=$ pt\&tlng=pt

7. Parreira JG, Farrath S, Soldá SC, Perlingeiro JAG, Assef JC. Comparative analysis of trauma characteristics between elderly and superelderly. Rev Col Bras Cir [Internet]. 2013 [acesso em 12 nov. 2018];40(4):269-74. Disponível em: http://www.scielo. br/pdf/rcbc/v40n4/en_v40n4a03.pdf

8. Vicente FR, Santos SMA. MultidimensionaL evaluation of determinants of active aging in older adults in a municipality in Santa Catarina. Texto \& Context Enferm [Internet]. 2013 [acesso em 12 jan. 2019];22(2):370-8. Disponível em: http://www. scielo.br/scielo.php?script=sci_arttext\&pid $=$ S010407072013000200013\&lng=pt\&nrm=iso\&t $\operatorname{lng}=$ en

9. Morais Neto OL, Montenegro MMS, Monteiro RAP, Siqueira Júnior JB, Marta Silva MMA, Lima CM, et al. Mortality due to Road Traffic Accidents in Brazil in the last decade: trends and risk clusters. Ciênc Saúde Colet [Internet]. 2012 [acesso em 13 jan. 2019];17(9):2223-36. Disponível em: http://www.scielo.br/scielo.php?script=sci_ arttext\&pid=S1413-81232012000900002\&lng=pt $\& \operatorname{lng}=\mathrm{pt}$

10. Mascarenas MDM, Barros MBA. Evolution of public health system hospital admissions due to external causes - Brazil, 2002-2011. Epidemiol Serv Saúde [Internet]. 2015 [acesso em 25 fev. 2019] 24(1):1929. Disponível em: http://www.scielo.br/pdf/ress/ v24n1/2237-9622-ress-24-01-00019.pdf

11. Andrade SSCA, Jorge MHPM. Hospitalization due to road traffic injuries in Brazil, 2013: hospital stay and costs. Epidemiol Serv Saúde [Internet]. 2017 [acesso em 18 fev. 2019];26(1):31-8. Disponível em: http://www.scielo.br/pdf/ress/v26n1/2237-9622ress-26-01-00031.pdf

12. Soares CB, Hoga LAK, Peduzzi M, Sangaleti C, Yonekura T, Silva DRAD. Integrative Review: concepts and methods used in nursing. Rev Esc Enferm USP [Internet]. 2014 [acesso em 29 jan. 2019];48(2):33545. http://www.scielo.br/scielo.php?script $=$ sci_ arttext\&pid=S0080-62342014000200335

13. Oliveira DC. Theme/Category-based Content Analysis: a proposal for systematization. Rev Enferm UERJ [Internet]. 2008 [acesso em 14 fev. 2019];16(4):569-76. Disponível em: http://www.facenf. uerj.br/v16n4/v16n4a19.pdf
14. Makizako H, Shimada H, Hotta R, Doi T, Tsutsumimoto K, Nakakubo S, et al. Associations of near-miss traffic incidents with attention and executive function among older japanese drivers. Gerontology [Internet]. 2018 [acesso em 17 fev. 2019];64(5):495-502. Disponível em: https://www. ncbi.nlm.nih.gov/pubmed/29428957

15. Heinrich D, Holzmann C, Wagner A, Fischer A, Pfeifer $\mathrm{H}$, Graw M, et al. What are the differences in injury patterns of young and elderly traffic accident fatalities considering death on scene and death in hospital? Int J Legal Med [Internet]. 2017 [acesso em 28 ago. 2019];131(4):1023-37. Disponível em: https:// www.ncbi.nlm.nih.gov/pubmed/28180986

16. Lombardi DA, Horrey WJ, Courtney TK. Age-related differences in fatal intersection crashes in the United States. Accid Anal Prev [Internet]. 2017 [acesso em 28 jan. 2019];99(Pt A):20-9. Disponível em: https://www. ncbi.nlm.nih.gov/pubmed/27855312

17. Matsui Y, Oikawa S, Hitosugi M. Features of fatal injuries in older cyclists in vehicle: bicycle accidents in Japan. Traffic Inj Prev [Internet]. 2017 [acesso em 17 jan. 2019];19(1):60-5. Disponível em: https://www. ncbi.nlm.nih.gov/pubmed/28581829

18. Chevalier A, Coxon K, Chevalier AJ, Clarke E, Rogers K, Brown J, et al. Predictors of older drivers' involvement in rapid deceleration events. Accid Anal Prev [Internet]. 2017 [acesso em 17 jan. 2019];98:3129. Disponível em: https://www.ncbi.nlm.nih.gov/ pubmed/27810673

19. Noh Y, Yoon Y. Elderly road collision injury outcomes associated with seat positions and seatbelt use in a rapidly aging society: a case study in South Korea. PLoS ONE [Internet]. 2017 [acesso em 17 jan. 2019];12(8):1-13. Disponível em: https://journals.plos. org/plosone/article?id=10.1371/journal.pone.0183043

20. Scolari GAS, Derhun FM, Rossoni DF, Mathias TAF, Fernando CAM, Carreira L. Trend in mortality of elderly by land transport accidents In Brazil. Cogitare Enferm [Internet]. 2017 [acesso em 17 jan. 2019];22(3):1-9. Disponível em: https://revistas.ufpr. br/cogitare/article/view/50170/pdf_en

21. Santos AMR, Rodrigues RAP, Diniz MA. Trauma by traffic accident in elderly people risk factors and consequences. Texto \& Contexto Enferm [Internet]. 2017 [acesso em 17 jan. 2019];26(2):2-10. Disponível em: http://www.scielo.br/pdf/tce/v26n2/pt_01040707-tce-26-02-e4220015.pdf

22. Niebuhr T, Junge M, Rosén E. Pedestrian injury risk and the effect of age. Accid Anal Prev [Internet]. 2016 [acesso em 17 jan. 2019];86:121-8. Disponível em: https://www.sciencedirect.com/science/article/pii/ S0001457515301081?via\%3Dihub 
23. Rudisill TM, Zhu M, Abate M, Davidov D, Delagarza V, Long DL, et al. The characterization of drug and alcohol use among senior drivers fatally injured in U.S. motor vehicle collisions, 2008-2012. Traffic Inj Prev [Internet]. 2016 [acesso em 17 jan. 2019];17(8):788-95. Disponível em: https://www.ncbi. nlm.nih.gov/pmc/articles/PMC5039044/

24. Yamani Y, Horrey WJ, Liang Y, Fisher DL. Agerelated differences in vehicle control and eye movement patterns at intersections: older and middleaged drivers. PLoS ONE [Internet]. 2016 [acesso em 17 jan. 2019];11(10):1-17. Disponível em: https:// journals.plos.org/plosone/article/file?id=10.1371/ journal.pone $.0164124 \&$ type $=$ printable

25. Silva HC, Pessoa RL, Menezes RMP. Trauma in elderly people: access to the health system through pre-hospital care. Rev Latinoam Enferm [Internet]. 2016 [acesso em 17 jan. 2019];24:1-8. Disponível em: http://www.scielo.br/pdf/rlae/v24/0104-1169rlae-24-02690.pdf

26. Almeida MHM, Caromano FA, Ribeiro SS, Batista MPP. An orientation program for elderly drivers with an emphasis on self-care practices. Rev Bras Geriatr Gerontol [Internet]. 2016 [acesso em 17 jan. 2019];19(2):303-11. Disponível em: http:// www.scielo.br/pdf/rbgg/v19n2/en_1809-9823rbgg-19-02-00303.pdf

27. Etehad H, Yousefzadeh-Chabok SH, DavoudiKiakalaye A, Dehnadi AM, Hemati H, MohtashamAmiri Z. Impact of road traffic accidents on the elderly. Arch Gerontol Geriatr [Internet]. 2015 [acesso em 17 jan. 2019];61(3):489-93. Disponível em: https:// www.ncbi.nlm.nih.gov/pubmed/26321733

28. Hong K, Lee KM, Jang S. Incidence and related factors of traffic accidents among the older population in a rapidly aging society. Arch Gerontol Geriatr [Internet]. 2015 [acesso em 17 jan. 2019];60(3):471-7. Disponível em: https:// www.sciencedirect.com/science/article/pii/ S0167494315000230

29. Freitas MG, Bonolo PF, Moraes EN, Machado CJ. Elderly patients attended in emergency health services in Brazil: a study for victims of falls and traffic accidents. Ciênc Saúde Colet [Internet]. 2015 [acesso em 17 jan. 2019];20(3):701-12. Disponível em: http://www.scielo.br/scielo.php?script $=$ sci_ arttext\&pid=S1413-81232015000300701

30. Shen S, Neyens DM. The effects of age, gender, and crash types on drivers' injury-related health care costs. Accid Anal Prev [Internet]. 2015 [acesso em 17 jan. 2019];77:82-90. Disponível em: https:// www.sciencedirect.com/science/article/pii/ S0001457515000251?via\%3Dihub
31. Zito GA, Cazzoli D, Scheffler L, Jäger M, Müri RM, Mosimann UP, et al. Street crossing behavior in younger and older pedestrians: an eye- and head-tracking study. BMC Geriatrics [Internet]. 2015 [acesso em 17 jan. 2019];15:1-10. Disponível em: https://bmcgeriatr.biomedcentral.com/track/ pdf/10.1186/s12877-015-0175-0

32. Dommes A, Cavallo V, Dubuisson JB, Tournier I, Vienne F. Crossing a two-way street: comparison of young and old pedestrians. J Safety Res [Internet]. 2014 [acesso em 17 jan. 2019];50:27-34. Disponível em: https://www.sciencedirect.com/science/article/ pii/S0022437514000395

33. Papa M, Boccardi V, Prestano R, Angellotti E, Desiderio M, Marano L, et al. Comorbidities and crash involvement among younger and older drivers. PloS ONE [Internet]. 2014 [acesso em 18 jan. 2019];9(4):1-6. Disponível em: https://journals.plos. org $/$ plosone/article?id=10.1371/journal.pone.0094564

34. Sandlin D, McGwin Jr G, Owsley C. Association between vision impairment and driving exposure in older adults aged 70 years and over: a population-based examination. Acta Ophthalmol [Internet]. 2014 [acesso em 17 jan. 2019];92(3):207-12. Disponível em: https:// onlinelibrary.wiley.com/doi/full/10.1111/aos.12050

35. Bell TM, Qiao N, Zarzaur BL. Mature driver laws and state predictors of motor vehicle crash fatality rates among the elderly: a cross-sectional ecological study. Traffic Inj Prev [Internet]. 2015 [acesso em 17 jan. 2019];16(7):669-76. Disponível em: https:// www.tandfonline.com/doi/full/10.1080/15389588. 2014.999858

36. Classen S, Wang Y, Crizzle AM, Winter SM, Lanford DN. Gender differences among older drivers in a comprehensive driving evaluation. Accid Anal Prev [Internet]. 2013 [acesso em 17 jan. 2019];61:146-52. Disponível em: https://linkinghub.elsevier.com/ retrieve/pii/S0001457512003661

37. Haleem K, Gan A. Effect of driver's age and side of impact on crash severity along urban freeways: a mixed logit approach. J Safety Res [Internet]. 2013 [acesso em 17 jan. 2019];46:67-76. Disponível em: https://www.sciencedirect.com/science/article/pii/ S0022437513000285?via\%3Dihub

38. Broska Júnior CA, Folchini AB, Ruediger RR. Comparative study of trauma in the elderly and nonelderly patients in a University Hospital in Curitiba. Rev Col Bras Cir [Internet]. 2013 [acesso em 17 jan. 2019];40(4):281-6. Disponível em: http://www.scielo. br/pdf/rcbc/v40n4/en_v40n4a05.pdf 